\title{
Autocrine TGF $\beta 1$ Opposes Exogenous TGF $\beta 1$-Induced Cell Migration and Growth Arrest through Sustainment of a Feed-Forward Loop Involving MEK-ERK Signaling
}

\author{
Hendrik Ungefroren ${ }^{1,2}, * \mathbb{D}$, Jessica Christl ${ }^{1}$, Caroline Eiden ${ }^{1}$, Ulrich F. Wellner ${ }^{3}{ }^{[}$, Hendrik Lehnert ${ }^{4}$ \\ and Jens-Uwe Marquardt ${ }^{1}$ \\ 1 First Department of Medicine, University Hospital Schleswig-Holstein, Campus Lübeck, \\ D-23538 Lübeck, Germany; jessica.christl@student.uni-luebeck.de (J.C.); \\ caroline.eiden@student.uni-luebeck.de (C.E.); Jens.Marquardt@uksh.de (J.-U.M.) \\ 2 Clinic for General Surgery, Visceral, Thoracic, Transplantation and Pediatric Surgery, University Hospital \\ Schleswig-Holstein, Campus Kiel, D-24105 Kiel, Germany \\ 3 Clinic for Surgery, University Hospital Schleswig-Holstein, Campus Lübeck, D-23538 Lübeck, Germany; \\ ulrich.wellner@uksh.de \\ 4 University of Salzburg, A-5020 Salzburg, Austria; hendrik.lehnert@sbg.ac.at \\ * Correspondence: hendrik.ungefroren@uksh.de
}

Citation: Ungefroren, H.; Christl, J.; Eiden, C.; Wellner, U.F.; Lehnert, H.; Marquardt, J.-U. Autocrine TGF $\beta 1$ Opposes Exogenous TGF $\beta 1$-Induced Cell Migration and Growth Arrest through Sustainment of a

Feed-Forward Loop Involving MEK-ERK Signaling. Cancers 2021, 13 , 1357. https://doi.org/doi:10.3390/ cancers13061357

Academic Editor: Noel F.C.C. De Miranda

Received: 24 January 2021

Accepted: 14 March 2021

Published: 17 March 2021

Publisher's Note: MDPI stays neutral with regard to jurisdictional claims in published maps and institutional affiliations.

Copyright: (c) 2021 by the authors. Licensee MDPI, Basel, Switzerland. This article is an open access article distributed under the terms and conditions of the Creative Commons Attribution (CC BY) license (https:/ / creativecommons.org/licenses/by/ $4.0 /)$.
Simple Summary: Transforming growth factor (TGF) $\beta$ signaling is intimately involved in nearly all aspects of tumor development and is known for its role as both a tumor suppressor in benign tissues and a tumor promoter in advanced cancers. This dual role is also reflected by cancer cell-produced TGF $\beta$ that eventually acts on the same cell(s) in an autocrine fashion. Recently, we observed that endogenous TGFB1 can inhibit rather than stimulate cell motility in cell lines with high autocrine TGF $\beta$ production. The unexpected anti-migratory role prompted us to evaluate how autocrine TGF $\beta 1$ impacts the cells' migratory and proliferative responses to exogenous (recombinant human) TGF $\beta$. Surprisingly, endogenous TGFB1 opposed the migratory and growth-inhibitory responses induced by exogenous TGF $\beta 1$ by driving a self-perpetuating feedforward loop involving MEK-ERK signaling. Our observation has implications for the use of TGF $\beta$ signaling inhibitors in cancer therapy.

Abstract: Autocrine transforming growth factor $\beta$ (aTGF $\beta$ ) has been implicated in the regulation of cell invasion and growth of several malignant cancers such as pancreatic ductal adenocarcinoma (PDAC) or triple-negative breast cancer (TNBC). Recently, we observed that endogenous TGFB1 can inhibit rather than stimulate cell motility in cell lines with high aTGF $\beta$ production and mutant KRAS, i.e., Panc1 (PDAC) and MDA-MB-231 (TNBC). The unexpected anti-migratory role prompted us to evaluate if aTGF $\beta 1$ may be able to antagonize the action of exogenous (recombinant human) TGF $\beta$ (rhTGF $\beta$ ), a well-known promoter of cell motility and growth arrest in these cells. Surprisingly, RNA interference-mediated knockdown of the endogenous TGFB1 sensitized genes involved in EMT and cell motility (i.e., SNAI1) to up-regulation by rhTGF $\beta 1$, which was associated with a more pronounced migratory response following rhTGF $\beta 1$ treatment. Ectopic expression of TGFB1 decreased both basal and rhTGF 31 -induced migratory activities in MDA-MB-231 cells but had the opposite effect in Panc1 cells. Moreover, silencing TGFB1 reduced basal proliferation and enhanced growth inhibition by rhTGF $\beta 1$ and induction of cyclin-dependent kinase inhibitor, $\mathrm{p} 21^{\mathrm{WAF}}$. Finally, we show that aTGF $\beta 1$ promotes MEK-ERK signaling and vice versa to form a self-perpetuating feedforward loop that is sensitive to SB431542, an inhibitor of the TGF $\beta$ type I receptor, ALK5. Together, these data suggest that in transformed cells an ALK5-MEK-ERK-aTGF $\beta 1$ pathway opposes the promigratory and growth-arresting function of rhTGF $\beta 1$. This observation has profound translational implications for TGF $\beta$ signaling in cancer.

Keywords: transforming growth factor $\beta$; pancreatic cancer; breast cancer; cell growth; autocrine regulation; extracellular-regulated kinase; WAF1; SNAIL 


\section{Introduction}

Pancreatic ductal adenocarcinoma (PDAC) and triple-negative breast cancer (TNBC) are among the most aggressive and early metastasizing tumors [1,2]. Their high mortality is caused in part by the late diagnosis, which often only occurs in an advanced disease state, emphasizing the need for the identification of reliable biomarkers for early diagnosis or prognosis [3,4]. Both cancer types are highly heterogeneous diseases characterized by diverse molecular and morphological features with the quasi-mesenchymal/squamous subtype of human PDAC [5] or basal-like subtype of $\mathrm{BC}$ [6] having the worst prognosis of any of the recently identified subtypes. Their poor treatment response and early resistance against conventional treatments eventually leads to aggressive metastatic disease. Aberrantly activated signaling pathways in PDAC and TNBC such as that of transforming growth factor $\beta$ (TGF $\beta$ ) were identified as drivers of mesenchymal/squamous differentiation due to the ability to induce epithelial-mesenchymal transition (EMT). This complex genetic program confers migratory and invasive properties to epithelial cells during cancer, therefore, linking aberrant TGF $\beta$ signaling and EMT to PDAC and TNBC aggressiveness, loss of growth inhibition, and resistance to chemo- and radiotherapy [7-9]. Although TGF $\beta$ pathways have been extensively studied, the mechanisms leading to cancer promotion and development are still not completely understood. The predominant genomic alteration in PDAC, and to a lesser extent in TNBC, affects the KRAS gene [10,11]. Persistent Kirsten Rat Sarcoma (KRAS)-epidermal growth factor receptor (EGFR) pathway activation cooperates with TGF $\beta$ signaling to endow PDAC and TNBC tumor cells with chemoresistance, metastatic dissemination, and early recurrence [1,10-12].

In malignant but not benign cells, TGF $\beta 1$ has been shown to potently auto-induce its own expression [13,14], which in proximal tubular epithelial cells requires the coordinated, but independent positive regulation by SMAD3, p38, and extracellular signal-regulated kinase (ERK) signaling [15]. We recently employed two human cancer cell lines with high autocrine TGF $\beta 1$ (aTGF $\beta 1$ ) production, namely Panc1, a PDAC-derived line with a quasi-mesenchymal signature, and MDA-MB-231, a TNBC-derived line of the basal-like subtype, to elucidate the underlying signaling pathways. We were able to identify the small GTPase, Ras-related C3 botulinum toxin substrate 1B (RAC1B), a splice isoform of RAC1 and powerful inhibitor of rhTGF $\beta 1$-induced cell migration, as an upstream activator of TGFB1 expression and TGF $\beta 1$ secretion [16]. In turn, aTGF $\beta 1$ induces SMAD3 protein expression [16] and basal p38 activation [17], suggesting their involvement in positive regulation of its own synthesis. However, whether aTGF $\beta 1$ also affects MEK-ERK signaling in PDAC and TNBC cells has not yet been analyzed.

It is generally believed that the ability to produce and secrete TGF $\beta$ that subsequently acts on the same cells or its neighbors in an autocrine or paracrine fashion can enhance a malignant phenotype [8]. However, a couple of observations suggest that endogenously produced aTGF $\beta$ and exogenous TGF $\beta$ can induce different signaling and target gene responses. For instance, endogenous TGF $\beta$ regulates the cell cycle through a pathway different from exogenous TGF $\beta$ with respect to sensitivity of effector proteins like cyclindependent kinase inhibitor 1 (p21 ${ }^{\mathrm{WAF} 1}$ ) and CDK4 [18]. Moreover, previous work indicated that aTGF $\beta$, rather than response to exogenous TGF $\beta$, is an important protector against malignant progression. For instance, constitutively repressing endogenous TGF $\beta 1$ expression and aTGF $\beta$ activity in human colon carcinoma cells retained their functional receptor complexes and the ability to respond to exogenous TGF $\beta$ but led to a more progressed phenotype [19]. In order to abrogate aTGF $\beta$ signaling, the majority of studies have used either dominant-negative inhibition [20-23], reconstitution of the type II receptor (T $\beta$ RII) [18,24], or inhibition of the activin receptor-like kinase 5 (ALK5) kinase activity [20,25-27] (for a comprehensive review see [28]). However, these approaches have important limitations for the following reasons: (i) they did not allow for a discrimination between the effects of the three different TGF $\beta$ isoforms, TGF $\beta 1$, 2, and 3, (ii) aTGF $\beta 1$ has been reported to be able to signal with respect to target gene expression, invasion but not proliferation in colon cancer cells that have lost the ability to produce functional T $\beta$ RII as a result of microsatellite 
instability [25], and (iii) they are expected to alter the response to both exogenous and aTGF $\beta 1$ and thus preclude an assessment of how exogenous TGF $\beta 1$ interacts with aTGF $\beta 1$. This is a serious issue since in most studies, experiments were performed in medium with $10 \%$ fetal bovine serum (FBS), which may have contained high concentrations of latent or bioactive TGF $\beta 1$. In the present study, we, therefore, chose a more specific approach by targeting the ligand, TGF $\beta 1$, directly through RNAi-mediated knockdown of TGFB1 to analyze how aTGF $\beta$ signaling impacts the chemokinetic and growth-inhibitory response to stimulation with exogenous, recombinant human TGF $\beta 1$ (rhTGF $\beta 1$ ). Our results provide evidence for the operation in cancer cells of an ALK5-MEK-ERK-aTGF $\beta 1$ pathway that opposes the promigratory and growth-arresting function of rhTGF $\beta 1$.

\section{Results}

\subsection{Divergent Effects of Endogenous and Exogenous TGF $\beta 1$ on TGF $\beta$ Target Genes}

Initially, we addressed the question of whether altering endogenous TGF $\beta 1$ levels would impact the response of EMT and invasion-associated genes to stimulation with exogenous rhTGF $\beta 1$. To this end, knocking down (KD) TGFB1 in Panc1 cells by $\mathrm{RNA}_{i}$ interference (Panc1 ${ }^{\text {TGFB1-KD }}$ ) significantly enhanced the stimulatory effect of rhTGF $\beta 1$ treatment on four invasion-promoting genes, SNAI1, SNAI2, SERPINE1 (encoding plasminogen activator-inhibitor type I, PAI-1), and F2RL1 (encoding proteinase-activated receptor 2, PAR2) (Figure 1A). Likewise, in MDA-MB-231 ${ }^{\text {TGFB1-KD }}$ cells, SNAI1, SNAI2, F2RL1 but not SERPINE1 were more responsive to rhTGF $\beta 1$ (Figure 1B). For SNAIL, this effect was confirmed at the protein level in Panc1 cells (Figure 1C, left-hand blot). We also noted a more pronounced down-regulation of E-cadherin in Panc1 ${ }^{\text {TGFB1-KD }}$ cells (Figure 1C, right-hand blot). Moreover, the number of spindle-shaped cells induced by treatment with rhTGF $\beta 1$ was greater in Panc1 ${ }^{\text {TGFB1-KD }}$ than in control cells (Figure S1). Together, the observed changes in the expression of master EMT regulators and in cellular morphology strongly suggest that endogenous TGF $\beta 1$ antagonizes rhTGF $\beta 1$-induced EMT.
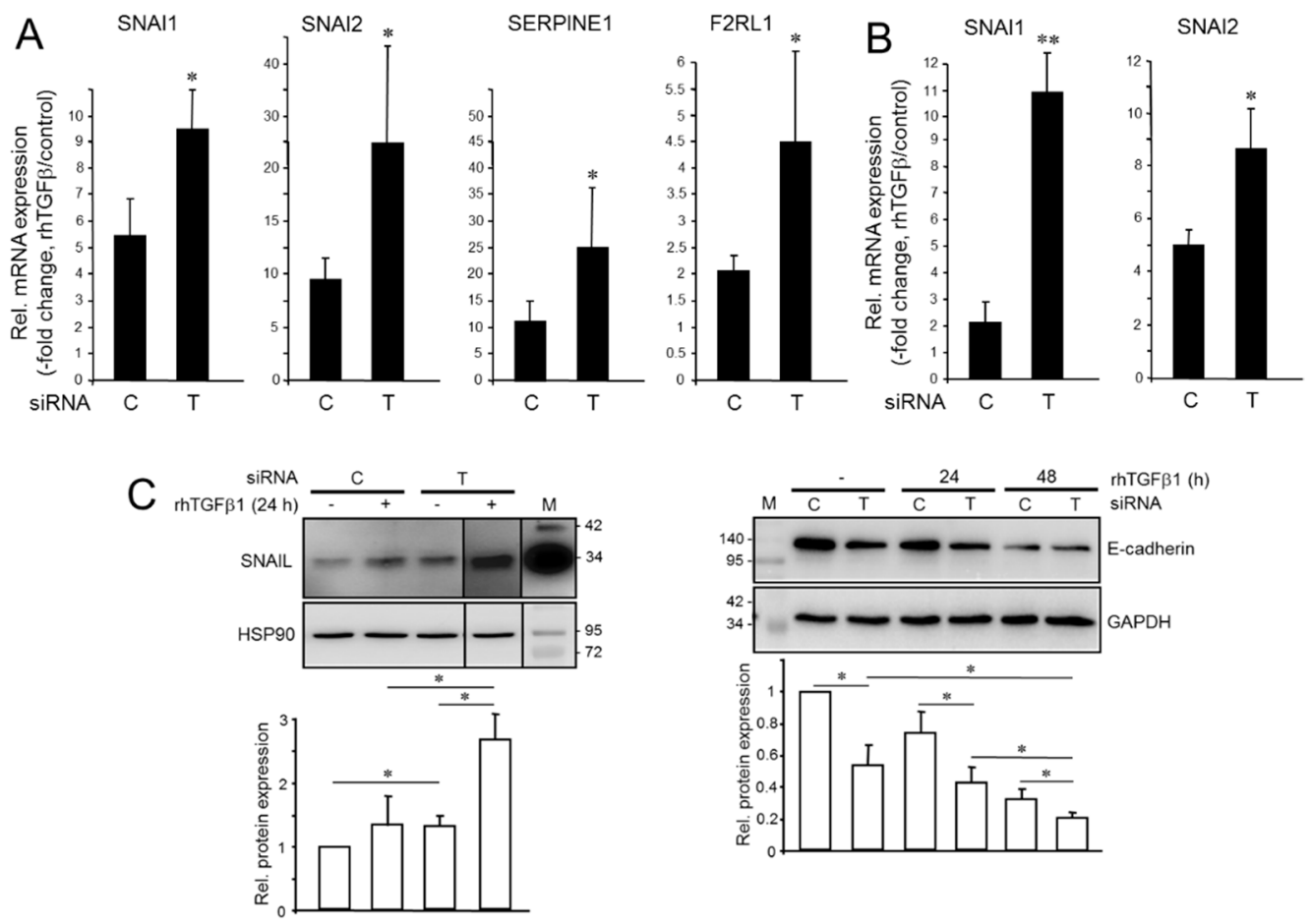

Figure 1. Effect of endogenous and recombinant human transforming growth factor $\beta 1$ (rhTGF $\beta 1$ ) on gene expression in tumor cells with aTGF $\beta$ production. (A) Panc1 ${ }^{\text {TGFB1-KD }}$ cells were transiently transfected twice on 2 consecutive days with $50 \mathrm{nM}$ each of siRNA directed against TGFB1 (T) or a scrambled control (C) siRNA and incubated for another $48 \mathrm{~h}$. Cells were then treated with rhTGF $\beta 1$ for $24 \mathrm{~h}$ and analyzed by qPCR for expression of the indicated genes and TATA box-binding 
protein (TBP) as a reference gene. Data are displayed as fold induction by rhTGF $\beta 1$ treatment over non-treated controls (means \pm SD; $n=3$ (SNAI1, SERPINE1), $n=4$ (SNAI2, F2RL1)). (B) As in (A) except that MDA-MB-231 TGFB1-KD were analyzed. (C) Western blot analysis of SNAIL (left-hand blot) and E-cadherin (right-hand blot) in Panc1 ${ }^{\text {TGFB1-KD }}$ cells treated, or not, with rhTGF $\beta 1$. Detection of heat shock protein 90 (HSP90) or glyceraldehyde 3-phosphate dehydrogenase (GAPDH) served as a loading control. The graphs below the blots show data quantification from densitometric readings of band intensities (mean $\pm \mathrm{SD}, n=3$ ). The asterisks denote significance. The vertical lines between lanes 3, 4, and 5 of the left blot indicate that irrelevant lanes have been removed. Successful knockdown of TGFB1 was verified by ELISA of secreted TGF $\beta 1$ in culture supernatants (Figure S2). M, molecular weight marker. Numbers to the right or left of the blots denote band sizes in $\mathrm{kDa} .{ }^{*}, p<0.05 ;{ }^{* *}, p<0.01$.

\subsection{Knockdown of TGFB1 Enhances the Migratory Response to rhTGF $\beta 1$}

Having shown that endogenous and $\operatorname{rhTGF} \beta 1$ display antagonistic effects on several invasion-associated genes, we asked whether depleting cells of endogenous TGFB1 expression would alter their sensitivity to rhTGF $\beta 1$-induced cell migration. Of note, under both basal conditions and in response to challenge with rhTGF $\beta 1$ MDA-MB-231 ${ }^{\text {TGFB1-KD }}$ or Panc1 $1^{\text {TGFB1-KD }}$ cells exhibited a dramatic increase in chemokinetic activity, which was particularly strong in Panc1 cells (Figure 2). Together, these data show that endogenous and exogenous rhTGF $\beta 1$ also exert antagonistic effects on cell migration and confirm the previous assumption that aTGF $\beta 1$ signaling may protect tumor cells from mesenchymal conversion and an associated increase in cell motility by non-autocrine, stromal cell-derived TGF $\beta 1$ [16].
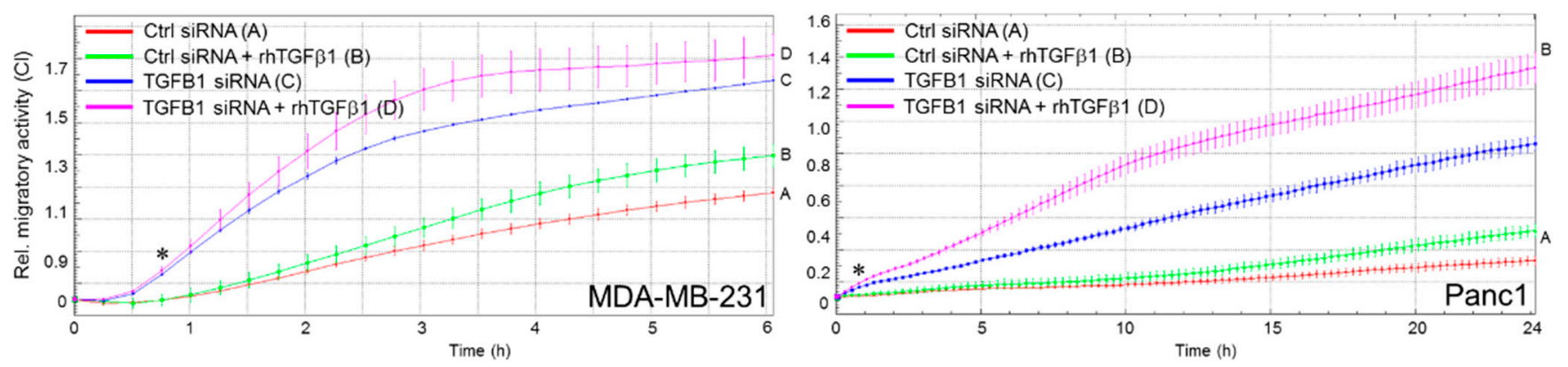

Figure 2. Effect of knockdown of endogenous TGFB1 on basal and rhTGFß1-dependent migration in triple-negative breast cancer (TNBC) and pancreatic ductal adenocarcinoma (PDAC)-derived tumor cells. MDA-MB-231 (left-hand graph) or Panc1 (right-hand graph) cells were transiently transfected with $50 \mathrm{nM}$ of either a scrambled control (Ctrl) siRNA or TGFB1 siRNA and $48 \mathrm{~h}$ later subjected to impedance-based real-time measurement of random cell migration in the presence of rhTGF $31(5 \mathrm{ng} / \mathrm{mL})$ for $24 \mathrm{~h}$. Data represent the mean \pm SD of 3-4 parallel wells for each condition. Differences between the green curves (tracing B) and the magenta curves (tracing D) were first significant at the 0:45 h time point $(*)$ and remained so during the entire observation period. Statistical significance was determined with the unpaired two-tailed Student's $t$-test from the raw data of the various curves. Successful knockdown of TGFB1 was verified by ELISA of secreted TGF $\beta 1$ in culture supernatants.

2.3. Ectopic TGFB1 Antagonizes Basal and rhTGFß1-Induced Migration in MDA-MB-231 Cells but Synergizes with rhTGFß1-Induced Migration in Panc1 Cells

Given the somehow paradoxical nature of aTGF $\beta 1$ being anti-migratory, we wanted to know how ectopic (over)expression of TGF $\beta 1$ from a transfected TGF $\beta 1$-encoding expression vector (pTGFB1) in the same cells impacts cell migration. In MDA-MB-231 cells, ectopic expression of TGF $\beta 1$ inhibited both basal and rhTGF $\beta 1$-induced migratory activities (Figure 3A). Surprisingly, however, when introduced into Panc1 cells, the ectopic TGF $\beta 1$ on its own enhanced rather than suppressed migration over that of vector controls and when combined with rhTGF $\beta 1$ further enhanced its pro-migratory effect (Figure $3 \mathrm{~B}$ ). Moreover, forced expression of TGFB1 synergized with RAC1B depletion in enhancing chemokinetic activity (Figure 3C, magenta curve/tracing D). Of note, enhanced migration of Panc1 cells in response to ectopic TGF $\beta 1$ expression was associated with increased 
activities of the SNAI1 and SNAI2 genes in Panc1 but not in MDA-MB-231 cells (Figure 3D). These results show that ectopically expressed TGF $\beta 1$ can either behave like aTGF $\beta 1$ and inhibit migration (in TNBC cells), or like rhTGF $\beta 1$ to stimulate migration (in PDAC cells). This is a significant observation given that both TGF $\beta$ s are derived from the same coding sequence (albeit from genes of different structure and nuclear localization) and produced and secreted in an autocrine fashion.
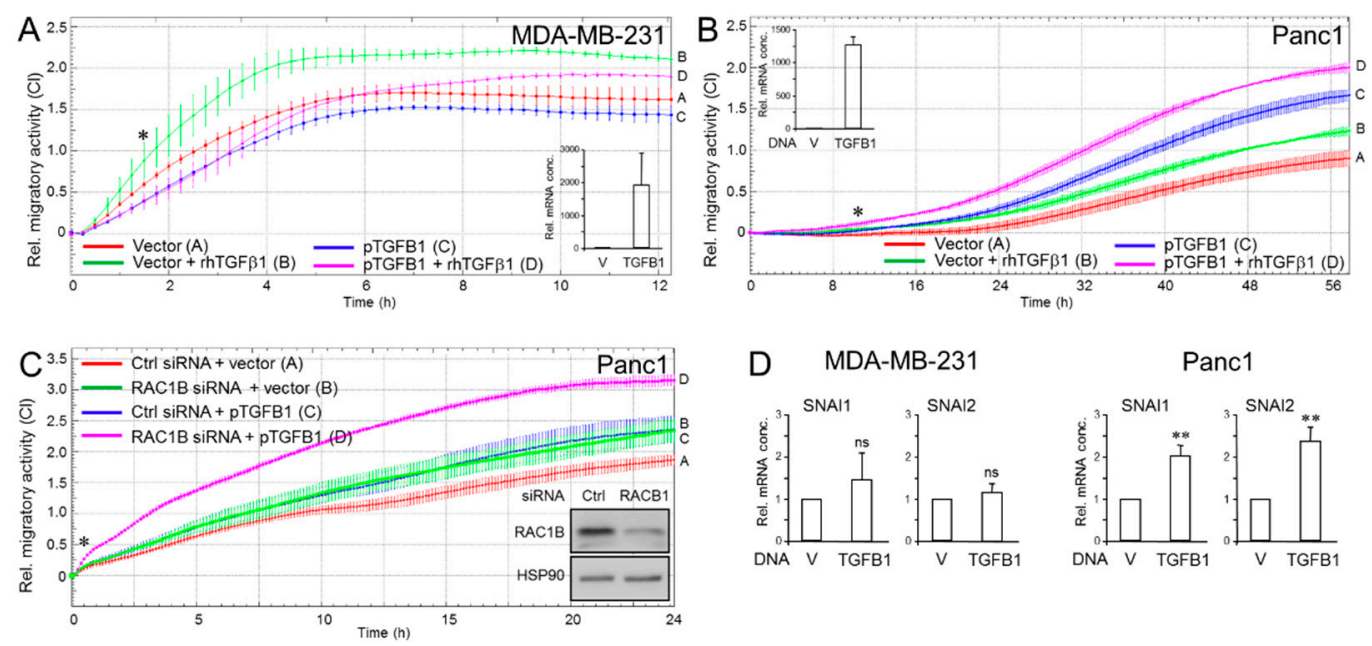

Figure 3. Effect of ectopic overexpression of TGFB1 in MDA-MB-231 and Panc1 cells on cell motility. (A) MDA-MB-231 cells were transfected with either empty vector or an expression vector encoding TGF $\beta 1$ (pTGFB1) and $48 \mathrm{~h}$ later subjected to real-time measurement of random cell migration in the absence or presence of rhTGF $\beta 1(5 \mathrm{ng} / \mathrm{mL})$. Differences between the green curve (tracing B) and the magenta curve (tracing D) were first significant at 1:30 $(*)$ and all later time points. (B) As in (A), except that Panc1 cells ectopically overexpressing TGF $\beta 1$ cells were assayed. Differences between the green curve (tracing B) and the magenta curve (tracing D) were first significant at 10:24 $(*$ ) and all later time points. Overexpression of transfected TGF $\beta 1$ in (A,B) was validated by qPCR analysis (insets), and by ELISA with culture supernatants from pTGFB1 transfected cells with or without the addition of rhTGF $\beta 1$ (Figure S3). (C) Panc1 cells were transiently cotransfected with Ctrl siRNA or RAC1B siRNA along with either empty vector or pTGFB1. Then, $48 \mathrm{~h}$ later the transfectants were analyzed on the $x$ CELLigence platform for changes in migratory activities. Differences between the green curve (tracing $B$ ) and the magenta curve (tracing D) were first significant at 1:00 $(*)$ and all later time points. Successful knockdown of RAC1B was verified by immunoblotting with HSP90 as loading control (inset). Data in (A-C) are the mean \pm SD from 3 or 4 parallel wells. (D) QPCR analysis SNAI1 and SNAI2 in MDA-MB-231 and Panc1 cells (mean \pm SD, $n=3$ ). V, empty vector; TGFB1, TGF $\beta 1$ expression vector. Ns, not significant. ${ }^{*}, p<0.05 ;{ }^{* *}, p<0.01$.

\subsection{Endogenous TGFB1 Opposes rhTGF $\beta 1-I n d u c e d$ Growth Arrest and Induction of p21 ${ }^{\text {WAF1 }}$ Expression}

Next, we asked if endogenous TGF $\beta 1$ impacts the well-known growth arresting function of rhTGF $\beta 1$ on Panc1 [29] and MDA-MB-231 [30] cells. We transfected both cell lines with TGFB1 siRNA and subsequently left the cells untreated or treated them for $50 \mathrm{~h}$ with rhTGF $\beta 1$ in normal growth medium. Results show that the silencing of endogenous TGFB1 alone greatly decreased the number of cells (Figure 4A). Moreover, the growthsuppressing effect of rhTGF $\beta 1$ was more pronounced in TGFB1-KD cells compared to rhTGF 31 -treated control cells (Figure 4A). Since we failed to detect any changes in the number of apoptotic cells among the various treatment groups, we conclude that reduced proliferative activity accounted for the lower cell counts in untreated and rhTGF $\beta 1$-treated TGFB1-KD cells.

TGF $\beta 1$ is known to induce growth arrest by up-regulating the expression of the cyclindependent kinase inhibitor, p21 ${ }^{\mathrm{WAF} 1}$, in pancreatic [29] and breast (Figure S4) epithelial cells. We, therefore, hypothesized that the reduced proliferative activity following TGFB1 silencing might have been caused by derepression of $\mathrm{p} 21^{\mathrm{WAF} 1}$. Strikingly, the abundance of 
p21 ${ }^{\text {WAF1 }}$ was enhanced in Panc1 ${ }^{\text {TGFB1-KD }}$ or MDA-MB-231 ${ }^{\text {TGFB1-KD }}$ cells vs. control transfectants and between non-rhTGF $\beta 1$-treated and rhTGF $\beta 1$-treated cells (Figure 4B). These data clearly show that aTGF $\beta 1$ opposes not only the pro-migratory effect of exogenous TGF $\beta 1$ but also its growth-suppressing function. Interfering with growth inhibition by exogenous TGF $\beta 1$ enhances mitotic activity, eventually resulting in a hyper-proliferative state that may have a role in early tumor development prior to mutational inactivation of Smad signaling.
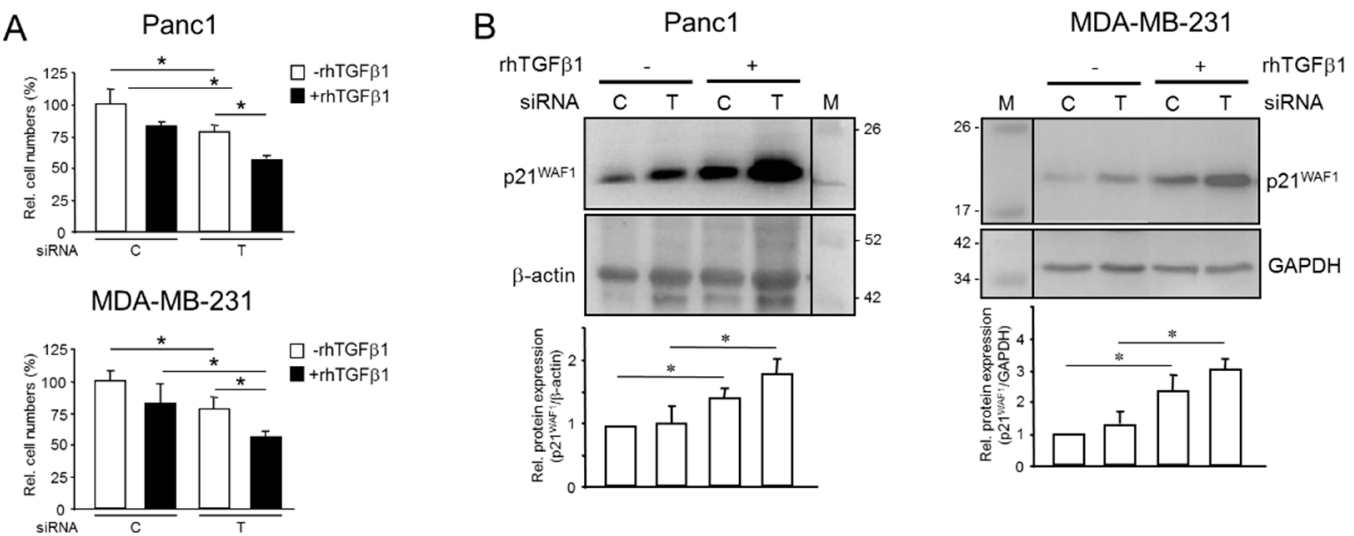

Figure 4. Effect of silencing TGFB1 on rhTGF $\beta 1$-induced growth arrest in pancreatic and breast cancer cells with aTGF $\beta$ production. (A) Panc1 or MDA-MB-231 cells were transiently transfected with $50 \mathrm{nM}$ of either control (C) siRNA or TGFB1 (T) siRNA and subsequently subjected to treatment with rhTGF $\beta 1(5 \mathrm{ng} / \mathrm{mL})$ for $50 \mathrm{~h}$. Cells were trypsinized and counted. Data (cell numbers) shown are representative of three assays, with non-rhTGF $\beta$-treated control transfectants set arbitrarily at 100 (mean $\pm \mathrm{SD}, n=3$ ). (B) Immunoblot analysis of $\mathrm{p} 21^{\mathrm{WAF} 1}$ in Panc1 or MDA-MB-231 cells transfected as outlined in (A) but treated with rhTGF $\beta 1$ for $24 \mathrm{~h}$. The graphs underneath the blots show results from densitometry-based quantification of band intensities (mean $\pm \mathrm{SD}, n=3)$. Successful knockdown of TGFB1 in $(\mathbf{A}, \mathbf{B})$ was verified by ELISA of secreted TGF $\beta 1$. The asterisks $(*)$ indicate significance $(p<0.05)$.

\subsection{Mutual Induction of aTGF $\beta 1$ or ERK Activation Sustains Proliferation}

Prompted by the stimulating effect of aTGF $\beta 1$ on basal proliferation and its antagonism on rhTGF $\beta 1$-induced growth arrest in Panc1 and MDA-MB-231 cells, we next sought to elucidate the signaling events underlying TGF $\beta 1$ auto-induction. A previous study in fibroblasts has shown the involvement of ERK MAPK signaling in TGF $\beta 1$ mRNA transcription [15]. To reveal whether ERK signaling is required for basal and rhTGF $\beta 1$-induced expression of aTGF $\beta 1$ in pancreatic cancer cells, we measured its expression by qPCR and ELISA in Panc1 cells that have been treated, or not, with rhTGF $\beta 1$ in the presence or absence of U0126, a selective MEK1/2 inhibitor [31]. U0126 specifically targeted ERK signaling for inhibition in Panc1 (Figure S5) and MDA-MB-231 cells (Figure S6), and in Panc1 cells had no effect on C-terminal phosphorylation (= activation) of SMAD3 by rhTGF $\beta 1$ (Figure S5). Intriguingly, the abundance of TGFB1 mRNA in both non-stimulated cells and rhTGF $\beta 1$-treated cells was dramatically reduced following inhibition of ERK activation (Figure 5A). Likewise, in U0126-treated cells the amount of TGF $\beta 1$ secreted into the culture medium was strongly decreased (Figure $5 B$ ).

Next, we focused on the role of the MEK-ERK pathway in auto-induction of TGF $\beta 1$. PDAC cells, i.e., Panc1, and TNBC MDA-MB-231 cells exhibit readily detectable levels of phosphorylated (p)ERK1/2 (Figures S5 and S6) as a result of oncogenic KRAS activity $[11,32,33]$. The activated ERK drives basal proliferation in these cells as evidenced by a dramatic decrease in DNA synthesis following inhibition of ERK activation with U0126 in Panc1 (Figure 5C) and MDA-MB-231 (Figure S7) cells. Since oncogenic KRAS ${ }^{\mathrm{G} 12 \mathrm{~V}}$ and $\mathrm{BRAF}^{\mathrm{V} 600 \mathrm{E}}$ [34] have been reported to stimulate aTGF $\beta 1$ production and both the mitogenic function and the auto-induction of TGF $\beta 1$ converged on ERK signaling in a prostate carcinoma cell line [35], we considered the possibility that aTGF $\beta 1$ itself is involved in sus- 
taining constitutive ERK activation. To this end, the levels of pERK1/2 in TGFB1-KD cells were found to be much lower than in control transfectants (Figure 5D). These data show that endogenous TGF $\beta 1$ and ERK signaling mutually enhance their expression/activation, eventually forming a self-perpetuating feedforward loop that drives basal proliferation and protect cells from the growth-suppressing effect of rhTGF $\beta 1$.

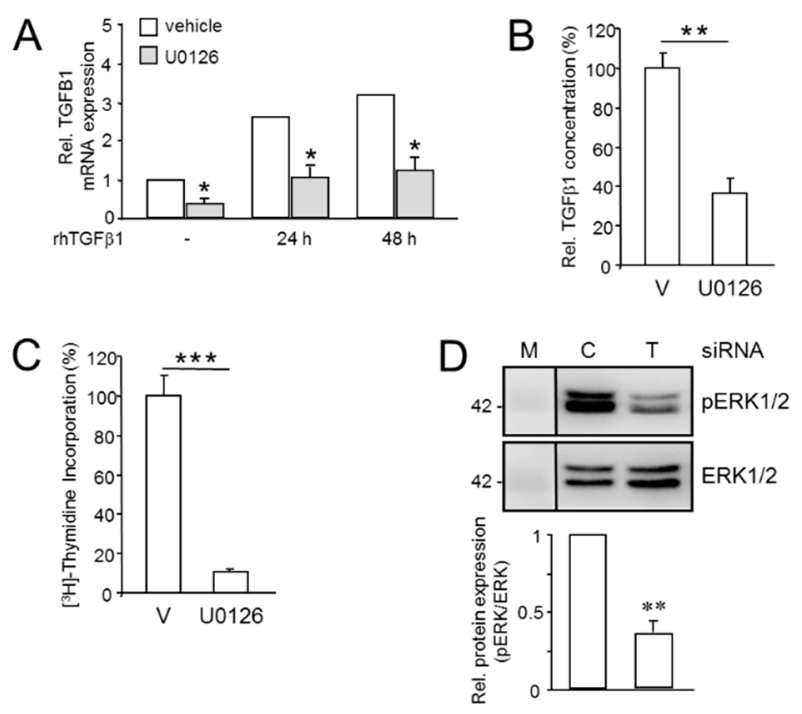

Figure 5. Mutual regulatory interactions between aTGF $\beta 1$ and ERK signaling enhances proliferation. (A) Panc1 cells were treated, or not (-), for 24 or $48 \mathrm{~h}$ with $\mathrm{rhTGF} \beta 1(5 \mathrm{ng} / \mathrm{mL})$ in the absence or presence of U0126 $(10 \mu \mathrm{M})$ or vehicle (0.1\% dimethyl sulfoxide, DMSO) followed by qPCR analysis of TGFB1 and GAPDH and TBP as internal control. Data represent the normalized mean \pm SD of triplicate wells from a representative experiment. The asterisks indicate significance relative to the vehicle ctrl. (B) As in (A), except that cells were switched to serum-reduced medium (0.5\% FBS) prior to U0126 treatment. Cells were allowed to condition their growth media for $24 \mathrm{~h}$. Aliquots of conditioned media were subjected to ELISA measurement of total (bioactive + latent) TGF $\beta 1$. Data are the mean \pm SD of triplicate samples. (C) Panc1 cells were treated, for $24 \mathrm{~h}$ with U0126 $(25 \mu \mathrm{M})$ or vehicle $(\mathrm{V})$ followed by $\left({ }^{3} \mathrm{H}\right)$-thymidine incorporation. Data shown are the mean $\pm \mathrm{SD}$ from 6 wells processed in parallel and are representative of 3 experiments. The asterisks indicate significance. (D) Panc1 cells were transfected with control or TGFB1 siRNA as described in the legend to Figure 1, $24 \mathrm{~h}$ later stimulated with rhTGF $\beta 1$ for $1 \mathrm{~h}$ and subjected to immunoblotting for phospho-ERK1/2 (pERK1/2), and total ERK1/2 as a loading control. Data represent the mean \pm SD from three independent assays. Successful knockdown of TGFB1 was verified by ELISA of secreted TGF $\beta 1$. The asterisks $(*)$ indicate significant differences relative to the respective controls. ${ }^{*}, p<0.05$; ${ }^{* *}, p<0.01 ; * * * 0.001$.

\subsection{Effect of Inhibition of the ALK5 Kinase on TGFB1 Expression, Cell Migration, and ERK2 Activation}

Previous studies have shown that TGF $\beta 1$ via ALK5 can activate ERK [36], an event that requires the ALK5 kinase and the adapter protein ShcA [37,38]. Moreover, treatment of MDA-MB-231 cells with SB431542 [30], a small molecule inhibitor of the ALK5 kinase [39], or of Panc1 cells with U0126 [40], increased the expression of p21 ${ }^{\mathrm{WAF} 1}$. We, therefore, considered the possibility that SB431542 disrupts the ERK-TGF $\beta 1$ loop leading to a decrease in ERK activation and TGFB1 expression and, as a consequence, to enhanced cell migration. Of note, the abundance of TGFB1 mRNA in Panc1 cells (Figure 6A), or secreted TGF $\beta 1$ protein in MDA-MB-231 cells (Figure S8A), was strongly reduced following SB431542 treatment, while that of the invasion-associated genes, SNAI1 and SERPINE1, in Panc1 cells was increased (Figure 6A). As control, we exposed Panc1 cells to a combination of SB431542 and rhTGF $\beta 1$, which, as expected, alleviated (auto)induction of TGFB1, SNAI1, and SERPINE1 by rhTGF $\beta 1$ (Figure 6A). Intriguingly, the SB431542 treatment also interfered with ERK 
activation (Figure 6B). Given the decrease in both TGFB1 mRNA and steady-state pERK levels and the increases in SNAI1 and SERPINE1 expression, we reasoned that this should impact the cells' propensity for cell migration. To this end, treatment of Panc1 cells with SB431542 but not PP2, a Src family kinase inhibitor that blocks TGF $\beta$ /Smad and p38 MAPK signaling in a Src-unrelated fashion [41], enhanced their chemokinetic activity (Figure 6C). Likewise, both Panc1 ${ }^{\text {TGFB1-KD }}$ and control cells responded to SB431542 treatment with elevated migration (Figure 6D). The promigratory effect of SB431542 was duplicated in MDA-MB-231 cells, while PP2 or the chemically related p38 MAPK inhibitor SB203580 had no effect (Figure S8B). Finally, we found that SB431542 but not SB203580 [42], decreased cell cycle progression as revealed by $\left({ }^{3} \mathrm{H}\right.$ )-thymidine incorporation (Figure 6E). The failure of siRNA-mediated knockdown of either mothers against decapentaplegic homolog 2 (SMAD2) or SMAD3 to decrease DNA synthesis (Figure 6F) revealed that the antiproliferative effect of SB431542 was not due to inhibition of the Smad-activating function of the ALK5 kinase. From these data, we conclude that TGFB1 expression, aTGF $\beta 1$-mediated inhibition of cell invasion, and promotion of growth is driven at least in part by the ability of ALK5 to induce MEK-ERK signaling.
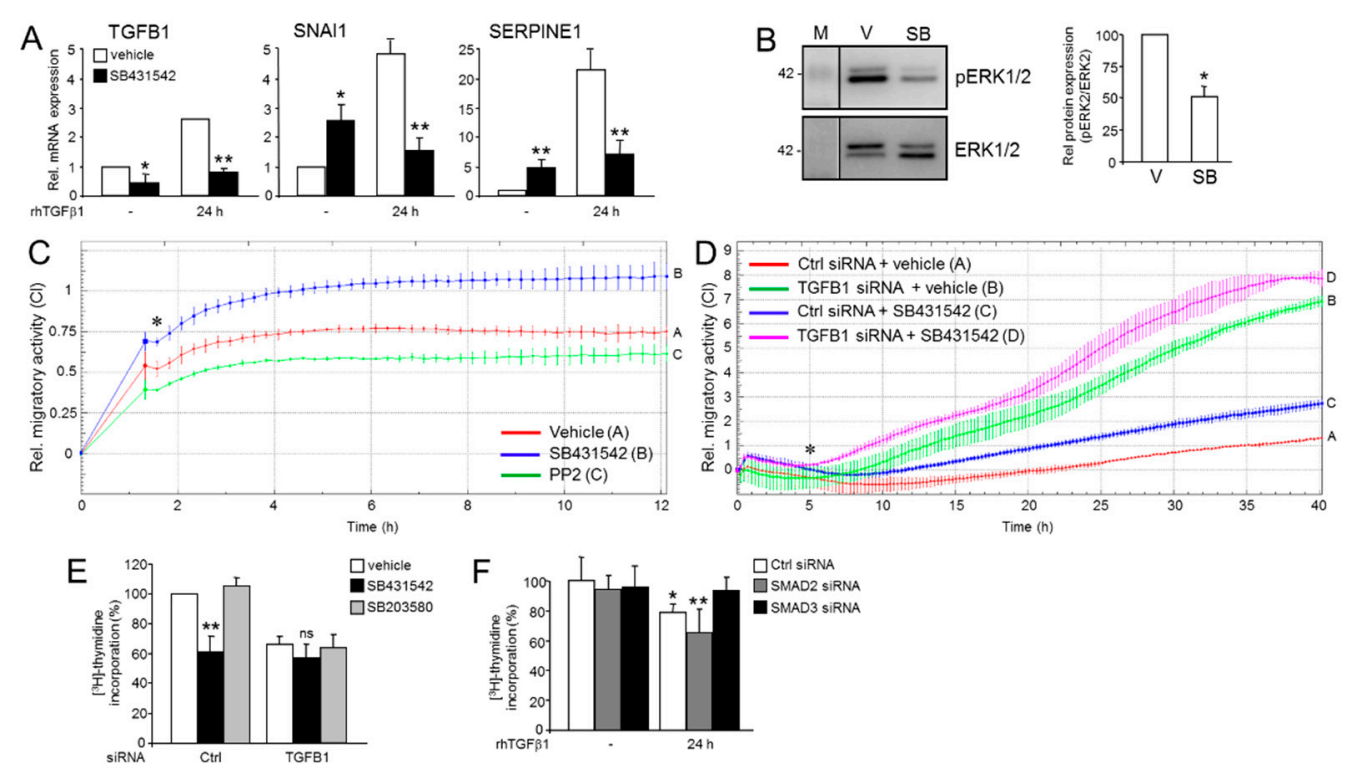

Figure 6. Effects of SB431542 on endogenous TGF $\beta 1$ expression, ERK activation, and cell migration. (A) Panc1 cells were treated, or not, for $24 \mathrm{~h}$ in the absence or presence of SB431542 $(1 \mu \mathrm{M})$, or vehicle $(0.1 \%$ DMSO followed by qPCR analysis of TGFB1, SNAI1 or SERPINE1 and GAPDH and TBP as internal control. Data represent the normalized mean \pm SD of triplicate wells from a representative experiment. The asterisks indicate significance relative to the vehicle control. (B) Panc1 cells were treated, or not, for $24 \mathrm{~h}$ with $1 \mu \mathrm{M}$ SB431542 or vehicle (V) followed by immunoblotting for pERK1/2 and ERK1/2 as loading control. The graph underneath the blots shows quantitative data (mean \pm SD from three independent assays). (C) Panc1 cells were subjected to real-time cell migration assay in the presence or absence of SB431542 (1 $\mu \mathrm{M})$ or PP2 $(10 \mu \mathrm{M})$. Mean \pm SD of triplicate wells. Differences between the red curve (tracing A) and the blue curve (tracing B) were first significant at 1:40 $(*)$ and all later time points. (D) Panc1 ${ }^{\text {TGFB1-KD }}$ and control (ctrl) cells were analyzed as in (C) in the presence or absence of SB431542 $(1 \mu \mathrm{M})$. Mean \pm SD of triplicate wells. Differences between the green curve (tracing B) and the magenta curve (tracing D) were first significant at 5:00 $(*)$ and all later time points. (E) Panc1 cells were treated, or not, for $24 \mathrm{~h}$ with the indicated concentrations of SB431542 or vehicle (V) followed by $\left({ }^{3} \mathrm{H}\right)$-thymidine incorporation. (F) Panc1 cells were transfected with siRNA to either SMAD2 or SMAD3, or a scrambled control (ctrl) siRNA, followed by $\left({ }^{3} \mathrm{H}\right)$-thymidine incorporation. Successful knockdown of SMAD2 and SMAD3 was verified by immunoblot analysis [43] and, functionally, by the ability of SMAD3 siRNA to block growth inhibition by rhTGF $\beta 1$ [44]. Data in (E,F) are the mean \pm SD from 6 wells processed in parallel and are representative of 5 and 3 experiments, respectively. The asterisks $(*)$ indicate significance compared to vehicle control; ${ }^{*} p<0.05 ;{ }^{* *}, p<0.01$; ns, not statistically significant. 


\section{Discussion}

Earlier experiments revealed that inhibition of aTGF $\beta 1$ in pancreatic and BC cells with known aTGF $\beta 1$ production, surprisingly, enhanced the cells' migratory activity and reduced basal proliferation [16], thus exhibiting effects antagonistic to those of rhTGF $\beta 1$. This prompted us to analyze how modulating endogenous TGF $\beta 1$ expression impacts the cells' response to treatment with exogenous (rh)TGF $\beta 1$. In the present study, we observed that silencing the endogenous TGFB1 gene in Panc1 or MDA-MB-231 cells reduced cell counts in the absence of exogenously applied rhTGF $\beta 1$, while strongly enhancing the stimulatory effect of exogenous/rhTGF $\beta 1$ on both invasion and growth inhibition. This resembled the situation with $\mathrm{RAC1B}$, consistent with its role as an upstream activator of endogenous TGFB1 and TGF $\beta 1$ secretion [16] and potent antagonist of rhTGF $\beta 1$-induced invasion and growth arrest [43].

We further observed that ectopically expressed TGF $\beta 1$ can behave as either endogenous or exogenous TGF $\beta 1$, depending on the cancer type. Intriguingly, the strong increase in rhTGF $\beta 1$-dependent migratory activity following blockage of aTGF $\beta$ synthesis/secretion was associated with a more pronounced induction by rhTGF $\beta 1$ of EMT/invasion-associated gene expression and the cell cycle inhibitor, $\mathrm{p} 21^{\mathrm{WAF} 1}$. As speculated earlier, low concentrations of aTGF $\beta 1$ may be able to desensitize the pathway and block the action of exogenous TGF $\beta 1$. It has, indeed, been reported that exposure of cells to low and high concentrations of TGF $\beta$ may have different and even opposing outcomes on cell migration [45].

The signaling events underlying the antagonism between endogenous and exogenous TGF $\beta 1$ nevertheless remains elusive but do not appear to involve quantitative changes in the expression of central TGF $\beta$ signaling intermediates such as ALK5 or SMAD7 [16]. Rather, we identified the MEK-ERK signaling pathway as a driver of both the mitogenic action of aTGF $\beta 1$ and endogenous TGFB1 expression under basal conditions and following stimulation with rhTGF $\beta 1$. This is consistent with reduced levels of DNA synthesis and pERK1/2 following either TGFB1 silencing, or pharmacologic MEK inhibition as control (Figure 5). Conversely, blocking ERK activation mitigated both basal and rhTGF $\beta 1$ induced TGFB1 expression. In fact, it appears that aTGF $\beta 1$ and MEK-ERK signaling mutually sustain their expression/activation to form a self-perpetuating feedforward loop that opposes the actions of exogenous TGF $\beta 1$ (Figure 7). Given the transcriptional up-regulation of TGFB1 by rhTGF $\beta 1$ and the functional antagonism between aTGF $\beta 1$ and rhTGF $\beta 1$ on cell motility and proliferation [16], this resembles the situation with the inhibitory Smad, SMAD7, which also acts as an endogenous albeit intracellular inhibitor of TGF $\beta$ signaling that provides feedback inhibition [46]. Interestingly, abrogation of aTGF $\beta$ signaling via dominant-negative interference with T $\beta$ RII or kinase inhibition of the type I receptor (T $\beta R I)$ ALK5 in a BC cell line decreased the levels of activated ERK but increased those of $\mathrm{p} 21^{\mathrm{WAF} 1}$ and induction of apoptosis [20]. Moreover, U0126-mediated inhibition of ERK activation has been shown by others to sensitize Panc1 cells to rhTGF $\beta 1$ induced up-regulation of p21 ${ }^{\mathrm{WAF} 1}$ [40], together suggesting that ERK opposes growthsuppressive TGF $\beta$ signals and promotes proliferation in the cancer state. This appears to be a distinguishing feature of transformed cells since during carcinogenesis, $p E R K$ initially facilitates and later antagonizes exogenous TGF $\beta$-mediated cell cycle arrest [40].

A growth-promoting effect of aTGF $\beta 1$ has been described previously in MDA-MB231 cells [47] and in colon carcinoma cells $[18,19]$ with aTGF $\beta$ regulating the cell cycle through a pathway different from exogenous TGF $\beta$ with respect to sensitivity of p21 WAF1 and CDK4 [18]. In a single prostate carcinoma cell line, the mitogenic function of TGF $\beta 1$ was dependent on ERK signaling [35]. However, the authors of this study have used rec. porcine TGF $\beta 1$ to stimulate their cells and to mimic the effect of aTGF $\beta$. Because of this variation and the lack of data showing that this cell line was indeed capable of TGF $\beta 1$ autoproduction, the data were not directly comparable with ours. Nevertheless, the authors provided evidence that mitogenic conversion of aTGF $\beta 1$ is dependent on oncogenic RAS proteins. Of note, proliferation and ERK signaling in both PDAC and TNBC-derived cells is driven by mutant KRAS, albeit different mutations, via activation of CRAF1, and both 
CRAF1 and BRAF ${ }^{\mathrm{V} 600 \mathrm{E}}$ [34] can induce TGF $\beta 1$ secretion. Moreover, activation of Raf in MDCK cells was able to block the ability of rhTGF $\beta$ to induce apoptosis [12], which is in good agreement with our data showing that aTGF $\beta$ interferes with rhTGF $\beta$-induced growth inhibition and migration.

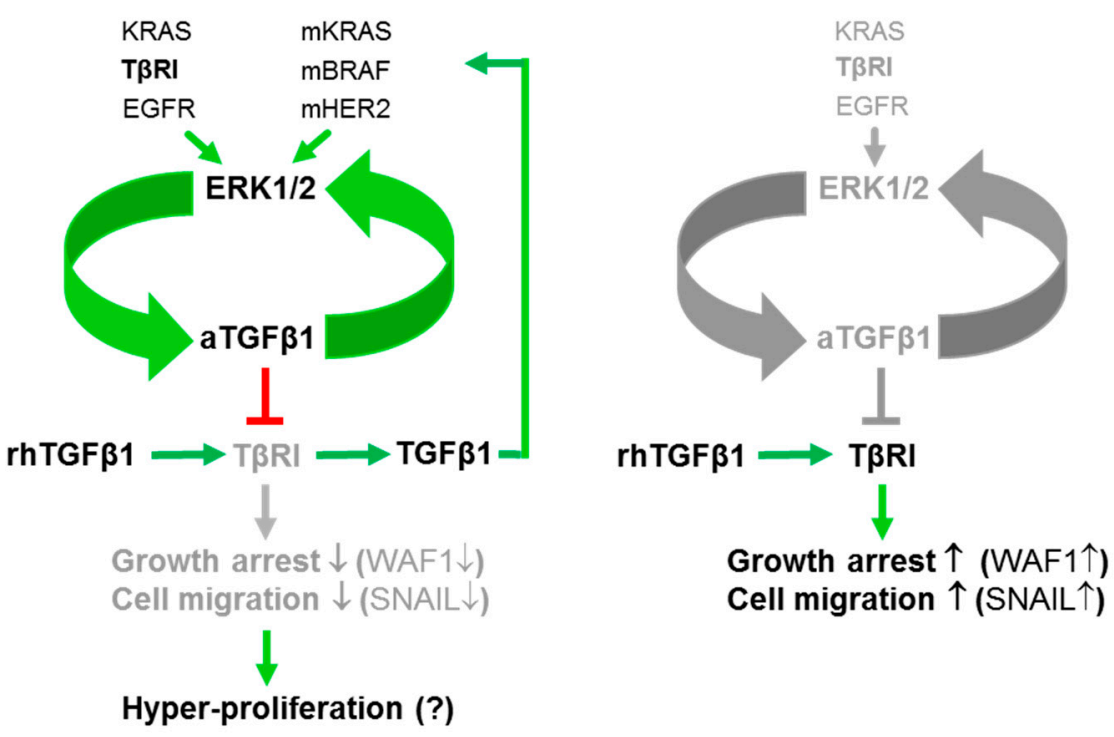

Figure 7. Cartoon illustrating the interactions of exogenous and endogenous/aTGF $\beta$ that operate in PDAC- and TNBC-derived tumor cells. Left-hand side, the aTGF $\beta 1$ forms a regulatory feedforward loop with ERK1/2 to sustain high-level ERK activation. This circuit prevents exogenous TGF $\beta 1$ (rhTGF $\beta 1$ in vitro or paracrine and stromal cell derived-TGF $\beta 1$ in vivo) from inducing growth arrest or cell migration through T $\beta$ R1/ALK5 via induction of $\mathrm{p} 21^{\mathrm{WAF} 1}$ (WAF1) or SNAIL, respectively. The aTGF $\beta 1-E R K$ loop is driven by mutant $(\mathrm{m})$ and wild-type versions of RAS, RAF, or EGFR/Erbb2 receptor tyrosine kinase 2 (HER2) and additionally through T $\beta$ RI/ALK5. Exogenous TGF $\beta 1$ also transcriptionally up-regulates TGFB1, and the resulting TGF $\beta 1$ protein via mutant RAS-ERK signaling can provide feedback inhibition of its own production. Right-hand side, in normal/benign cells, the aTGF $\beta 1$-ERK autoregulatory loop is non-functional due to the lack of mutant RAS/RAF proteins or lower expression or activation of T $\beta$ RI/ALK5, but low-level activation of the aTGF $\beta 1$-ERK circuit is eventually achieved through EGFR activation via (wild-type) RAS. Green arrows denote activation or induction and red lines inhibition. Grey-shaded arrows/lines indicate inactivation.

Another interesting issue relates to the question of whether MEK-ERK signaling and aTGF $\beta 1$ production can also be triggered by wild-type RAS proteins and, if so, what the upstream activator(s) are. In Panc1 cells, further ERK activation is induced by mitogenic stimuli [33] due to activation of KRAS protein encoded by the wild-type allele. A likely candidate is EGF, which is a strong inducer of MEK-ERK signaling in Panc1 (Figure S5) and other cell types and may be able to target this newly identified pro-proliferative circuit of aTGF $\beta 1$-ERK to antagonize growth arrest by exogenous TGF $\beta 1$ (Figure 7). Interestingly, EGF has been shown to abrogate the antiproliferative effects of rhTGF $\beta$ in primary human ovarian cancer cells, representing a potential non-mutational mechanism in cells lacking mutations in SMAD4, or the receptors, to inhibit exogenous TGF $\beta$ signaling and contributing to uncontrolled proliferation [48]. Likewise, in mammary epithelial cells, expression of mutant HER2 or HRAS ${ }^{\mathrm{G} 12 \mathrm{~V}}$ activated aTGF $\beta 1$ expression and signaling through a mechanism involving activation of RAC1 [49]. Here, we pursued the idea of direct ERK activation by the TGF $\beta$ receptor(s) based on the realization that ALK5 is a dual-specificity kinase, with its tyrosine kinase function being able to directly phosphorylate ShcA [37,38]. Tyrosine phosphorylation of ShcA by ALK5 is dependent on the kinase domain and is inhibitable by SB431542 [37]. Intriguingly, blocking the ALK5 kinase with 
SB431542 in Panc1 or MDA-MB-231 cells decreased the abundance of TGFB1 mRNA or secreted TGF $\beta 1$ protein and $\mathrm{pERK}$ and enhanced invasive gene expression and chemokinesis, thus mimicking the inductive effect of TGFB1 silencing on cell motility. Moreover, treatment with SB431542 reduced the basal proliferation of Panc1 cells in a Smad and p38 MAPK-independent manner. Together with the observation that SB431542 inhibited cell growth with up-regulation of $\mathrm{p} 21^{\text {WAF1 }}$ expression in MDA-MB-231 and other non-BC cell lines [30], we arrived at the conclusion that ALK5-mediated activation of MEK-ERK signaling accounts, at least in part, for fueling and sustaining the ERK-aTGF $\beta 1$ regulatory loop (Figure 7). Another observation by Koo and colleagues [30], namely, that treatment with SB431542 resulted in down-regulation of the transcription factor Sp1 together with the notion that TGFB1 but not TGFB2 is transcriptionally regulated by Sp1 [50] provided a possible mechanistic explanation of how the ALK5-MEK-ERK non-canonical pathway drives aTGF $\beta 1$ synthesis.

Further studies are underway to clarify if ShcA represents an upstream driver of this process. Silencing ShcA expression in non-transformed cells (NMuMG, HaCaT) induced EMT, cell migration, invasion, and dissemination, which was dependent upon aTGF- $\beta$ signaling. However, rather than modulating EMT through the Erk pathway ShcA acted through suppressing Smad3 activation by competing with Smad3 for binding to ALK5 [38]. It, therefore, appears that during (Ras-induced) transformation, cells have switched the coupling of aTGF $\beta$ production from Smad to ERK signaling, paralleling the mitogenic switch of ERK [40].

Differential responsiveness of cells to autocrine and exogenous TGF $\beta 1$ has been described with both exhibiting differences in signaling, particularly in their requirements for the different receptor types. Specifically, functional T $\beta$ RII has been shown to be dispensable for autocrine but not exogenous TGF $\beta 1$ [25], representing a potential mechanism to separate cellular responses to TGF $\beta 1$ from autocrine sources and from paracrine sources. Previous findings from our laboratory indicated that TGFB1 silencing did not alter the abundance of SMAD7 mRNA or ALK5 protein expression [16]. An elucidation of the different receptors and co-receptors utilized by endogenous and exogenous TGF $\beta$, their subcellular localization, and state of activation seems to be key to better understand the functional antagonism.

Interestingly, TGFB1 silencing allowed for enhanced induction by rhTGF $\beta 1$ of other prominent target genes, i.e., SNAI1 and WAF1, providing a molecular framework for the inhibitory effect of aTGF $\beta 1$ on rhTGF $\beta 1$-induced invasion and growth arrest. In a prostate cancer cell line, where mitogenic conversion of TGF $\beta 1$ required oncogenic HRAS ${ }^{G 12 V}$, p21 ${ }^{\mathrm{WAF} 1}$ has been identified as a potential executor of this program [35]. Interestingly, both Panc1 and MDA-MB-231 cells contain gain-of-function mutations in KRAS (G12V and G13D, respectively) that are known to drive constitutive ERK signaling [51] and suppress p $21^{\text {WAF1 }}$ in these cells. Moreover, induction of SNAI1 by rhTGF $\beta 1$ in Panc1 cells, which was greatly enhanced in TGFB1-KD cells (Figure 1B), is known to repress proliferation [52] and to be highly dependent on cooperation with active KRAS [32] and on MEK-ERK signaling [53].

An intriguing observation was that although both autocrine and ectopically expressed TGF $\beta 1$ were expressed and secreted by the same cells, they both inhibited cell invasion in MDA-MB-231 cells but displayed antagonistic effects in Panc1 cells. An explanation of why in pancreatic cells ectopic TGF $\beta 1$ behaves like exogenous TGF $\beta 1$ is not readily available but we are currently trying to decipher whether differences in total expression or conversion from latent to bioactive TGF $\beta 1$ account for this.

The finding that aTGF $\beta 1$ impairs invasive activities induced by exogenous/rhTGF $\beta 1$ suggests an anti-oncogenic function in late-stage carcinomas when malignant progression is largely driven by high concentrations of stromal cell-derived TGF $\beta 1$ in the tumor microenvironment. However, the ability of aTGF $\beta 1$ to interfere with the growth-arresting and, hence, tumor-suppressive function of (exogenous) TGF $\beta 1$ also makes it a potential oncogenic driver in early PDAC and BC development. Interestingly, murine pre-neoplastic 
pancreatic epithelial cells with mutant KRAS transiently exposed to exogenous TGF $\beta 1$, i.e., corresponding in vivo to pulses of TGF $\beta 1$ produced during chronic pancreatitis, a known risk factor for PDAC [54], converted to a partially mesenchymal (PM), progenitor-like, and hyper-proliferative state in vitro, which was stable and maintained by aTGF $\beta$ [27]. These PM cells, like Panc1, shared molecular and phenotypic features with the quasimesenchymal subtype of human PDAC and in vivo formed ductal structures resembling human PanINs. Unfortunately, a mechanistic explanation for the hyper-proliferation was not supplied in this study, but it is conceivable that it resulted-at least in part-from aTGF $\beta 1$ blocking the growth-inhibitory effect of exogenous TGF $\beta 1$. It is tempting to speculate that a finely tuned balance of the opposing actions of aTGF $\beta$ and exogenous TGF $\beta 1$ does not only control invasion and proliferation, but by inducing a partial/hybrid EMT also generates cancer stem cells and promotes resistance to anti-cancer drugs $[55,56]$.

\section{Materials and Methods}

\subsection{Cell Lines and Treatments}

The PDAC-derived cell line, Panc1, and the TNBC-derived cell line, MDA-MB-231, were propagated in RPMI 1640 basal medium supplemented with 10\% FBS, 1\% PenicillinStreptomycin-Glutamine (PSG, Life Technologies, Darmstadt, Germany) and 1\% sodium pyruvate (Merck Millipore, Darmstadt, Germany). In some experiments, cells were stimulated with 5 or $10 \mathrm{ng} / \mathrm{mL}$ of human either rhTGF $\beta 1$ (\#300-023, ReliaTech, Wolfenbüttel, Germany) or EGF (PeproTech, Hamburg, Germany). The MEK inhibitor U0126, the Src family kinase inhibitor PP2, the p38 MAPK inhibitor SB203580, and the Rac1 inhibitor NSC23766 [57] were purchased from Calbiochem/Merck (Darmstadt, Germany), and the ALK5 inhibitor SB431542 from Sigma (Deisenhofen, Germany).

\subsection{Transient Transfections}

For transient transfection, cells were seeded on day 1 into 12-well plates (Nunc, Roskilde, Denmark) and transfected twice, on days 2 and 3, serum-free with either 25 or $50 \mathrm{nM}$ of prevalidated siRNAs specific for RAC1B or the respective scrambled controls. The TGFB1 siRNA (\#1027416, a mixture of four different pre-evaluated siRNAs) was provided by Dharmacon (Lafayette, CO, USA) and the SMAD2 and SMAD3 siRNAs from Qiagen (Hilden, Germany). An expression vector for full-length human TGFß1 (\#SC119746) was purchased from OriGene Technologies Inc. (Rockville, MD, USA). SiRNAs or plasmids were transfected into cells serum-free for $4 \mathrm{~h}$ using Lipofectamine 2000 (Life Technologies) according to the manufacturer's recommendations and previous descriptions $[16,17,43]$.

\subsection{Quantitative Real-Time PCR Analysis}

Total RNA was isolated from Panc1 or MDA-MB-231 cells with the RNeasy Kit (Qiagen, Hilden, Germany) according to manufacturer's instructions. For each sample, $2.5 \mu \mathrm{g}$ RNA was reverse transcribed with $200 \mathrm{U}$ of M-MLV Reverse Transcriptase and $2.5 \mu \mathrm{M}$ random hexamers $\left(1 \mathrm{~h}, 37^{\circ} \mathrm{C}\right)$. Target gene mRNA expression was quantified by qPCR on an ICycler (BioRad, Munich, Germany) with Maxima SYBR Green Master Mix (Thermo Fisher Scientific, Schwerte, Germany) and normalized to the expression of either TBP or GAPDH. PCR primer sequences are provided in Table S1.

\subsection{Western Blotting}

Our Western blotting procedure was described in detail earlier [16,17,43]. Total protein concentrations were determined with the DC Protein Assay (BioRad). Proteins were fractionated by PAGE on mini-PROTEAN TGX any-kD precast gels and blotted onto PVDF membranes. The primary antibodies included anti-HSP90 (Santa Cruz Biotechnology, Heidelberg, Germany, \#sc-13119), anti-Rac1b (Merck Millipore, Darmstadt, Germany, \#09-271), anti-E-cadherin and anti-Cip1/WAF1 (BD Transduction Laboratories, Heidelberg, Germany, \#610181 and \#610233, respectively), anti-Snail and anti-phospho-ERK1/2 (Cell Signaling Technology, Frankfurt/Main, Germany, \#4719 and \#4370, respectively), 
anti-ERK1/2 (R\&D Systems, Wiesbaden, Germany, \#AF1576), anti-GAPDH (14C10, Cell Signaling Technology, \#2118), and anti- $\beta$-actin (Sigma). Incubation with HRP-linked secondary antibodies (Cell Signaling Technology, anti-rabbit, \#7074, and anti-mouse, \#7076) was followed by chemoluminescent detection of proteins on a ChemiDoc XRS+ System with Image Lab Software (BioRad) using Amersham ECL Prime Detection Reagent (GE Healthcare, Munich, Germany). The signals for the proteins of interest were normalized to bands for the housekeeping genes GAPDH or HSP90.

\subsection{TGF $\beta 1$ ELISA}

ELISA-based measurements of TGF $\beta 1$ were performed as described in detail earlier [16,17] using the TGF $\beta 1$-specific ELISA (Human/Mouse TGF beta1 ELISA Ready-SETGo!) from eBioscience/Affymetrix Inc. (San Diego, CA, USA) with the only modification that total rather than bioactive TGF $\beta 1$ was measured.

\section{6. $\left({ }^{3} \mathrm{H}\right)$-Thymidine Incorporation Assay}

Labeling of the cells with methyl $\left({ }^{3} \mathrm{H}\right)$-thymidine was essentially done as outlined in detailed earlier with minor modifications [29].

\subsection{Real-Time Cell Migration Assays}

Migratory activities of Panc1 and MDA-MB-231 cells were determined with xCELLigence ${ }^{\circledR}$ technology (Agilent Technologies, Santa Clara, CA, USA, supplied by OLS, Bremen, Germany) as outlined in detail in the instruction manual and previous publications $[16,17,43]$ except for some modifications. The lower side of the membrane of the CIM-Plate 16 (https: / / www.agilent.com/en/product/cell-analysis/real-time-cell-analysis /rtca-microplates / rtca-cim-plates-741221\#productdetails (accessed on 2 March 2021)) was coated with $30 \mu \mathrm{L}$ of a 1:1 $(v / v)$ mixture of collagens I and IV to facilitate adherence of the cells and to enhance signal intensities. A total of 60,000 cells transfected with either ctrl or TGFB1 siRNA and resuspended in serum-reduced ( $1 \%$ FBS) culture medium were loaded per well, and in some experiments, half of each transfectant received $\mathrm{rhTGF} \beta 1(5 \mathrm{ng} / \mathrm{mL})$ or vehicle.

\subsection{Proliferation Assays}

Panc1 or MDA-MB-231 cells were seeded at 100,000 cells per 12-well and transfected the next day and the day after with $50 \mathrm{nM}$ each of ctrl siRNA or TGFB1 siRNA as outlined above. Four hours after the second round of transfection, cells were detached and seeded at 50,000 cells per 6 well. Following reattachment (16 h later), cells were stimulated with rhTGF $\beta 1$ (Panc1: $5 \mathrm{ng} / \mathrm{mL}$, MDA-MB-231: $10 \mathrm{ng} / \mathrm{mL}$ ) for $50 \mathrm{~h}$, lifted by trypsinization and counted using the Cedex XS device (Roche Diagnostics, Mannheim, Germany).

\subsection{Statistical Analysis}

Statistical significance was calculated using either the unpaired two-tailed Student's $t$-test or the Wilcoxon-test. Results were deemed significant at $p<0.05$ (denoted by one asterisk). For some data, higher levels of significance were calculated and denoted by two or three asterisks $(p<0.01$ or $p<0.001$, respectively).

\section{Conclusions}

Given the current concept of autocrine TGF $\beta$ as a driver of tumor progression, our observation that endogenous autocrine TGF $\beta 1$ can also block cell motility was surprising and provoked the question how modulating expression of TGFB1 impacts the migratory and proliferative responses to exogenous/recombinant human TGF $\beta 1$. Surprisingly, silencing endogenous TGFB1 in PDAC and TNBC-derived cancer cells with known autocrine TGF $\beta 1$ production allowed exogenous TGF $\beta 1$ to elicit a more pronounced migratory and growth-inhibitory response. This can be interpreted to mean that in vivo cancer cells utilize autocrine TGF $\beta 1$ to protect themselves against the actions of stromal cell-derived paracrine TGF $\beta$ and suggest the possibility that a finely tuned balance of the antagonistic actions of 
autocrine and exogenous TGF $\beta(1)$ also controls the generation of EMT phenotypes with enhanced plasticity and stem cell potential. Last but not least, our data challenge the view that autocrine TGF $\beta$ production is always a feature of the "dark side" of TGF $\beta$ in cancer progression.

Supplementary Materials: The following are available online at https:/ /www.mdpi.com/2072-669 4/13/6/1357/s1, Figure S1: Effect of knockdown of TGFB1 on recombinant human transforming growth factor $\beta 1$ (rhTGF $\beta 1$ )-induced changes in cell morphology of Panc1 cells. Figure S2: Validation of successful TGFB1 knockdown in Panc1 and MDA-MB-231 cells; Figure S3: Content of TGF $\beta 1$ in culture supernatants from Panc1 and MDA-MB-231 cells with ectopic TGF $\beta 1$ expression and added rhTGF $\beta 1$; Figure S4: Induction of p21WAF1 by rhTGF $\beta 1$ in breast epithelial cells; Figure S5: U0126 blocks activation of ERK1/2 but not rhTGF $\beta 1$-induced activation of SMAD3 [58]; Figure S6: The MEK inhibitor U0126 inhibits ERK activation in MDA-MB-231 cells; Figure S7: Inhibition of ERK activation inhibits proliferation in MDA-MB-231 cells; Figure S8: Effects of SB431542 on endogenous TGF $\beta 1$ secretion and cell migration in triple-negative breast cancer (TNBC) cells; Table S1: Primers used for qPCR.

Author Contributions: Conceptualization, H.U.; formal analysis, H.U.; funding acquisition, H.L. and J.-U.M.; investigation, H.U., J.C., C.E. and U.F.W.; project administration, H.U.; resources, U.F.W.; writing-original draft, H.U.; writing—review and editing, U.F.W., H.L. and J.-U.M. All authors have read and agreed to the published version of the manuscript.

Funding: This research received no external funding.

Institutional Review Board Statement: Not applicable.

Informed Consent Statement: Not applicable.

Data Availability Statement: Data are contained within the article or Supplementary Material.

Acknowledgments: We are indebted to H. Albrecht for excellent technical assistance.

Conflicts of Interest: The authors declare no conflict of interest.

\section{References}

1. Hezel, A.F.; Kimmelman, A.C.; Stanger, B.Z.; Bardeesy, N.; Depinho, R.A. Genetics and biology of pancreatic ductal adenocarcinoma. Genes Dev. 2006, 20, 1218-1249. [CrossRef] [PubMed]

2. Ali, A.M.; Ansari, J.A.K.; El-Aziz, N.M.A.; Abozeed, W.N.; Warith, A.M.A.; Alsaleh, K.; Nabholtz, J.M. Triple Negative Breast Cancer: A Tale of Two Decades. Anticancer Agents Med. Chem. 2017, 17, 491-499. [CrossRef] [PubMed]

3. Brancaccio, M.; Natale, F.; Falco, G.; Angrisano, T. Cell-Free DNA Methylation: The New Frontiers of Pancreatic Cancer Biomarkers' Discovery. Genes 2019, 11, 14. [CrossRef] [PubMed]

4. Shah, R.; Rosso, K.; Nathanson, S.D. Pathogenesis, prevention, diagnosis and treatment of breast cancer. World J. Clin. Oncol. 2014, 5, 283-298. [CrossRef]

5. Torres, C.; Grippo, P.J. Pancreatic cancer subtypes: A roadmap for precision medicine. Ann. Med. 2018, 50, 277-287. [CrossRef]

6. Shao, F.; Sun, H.; Deng, C.X. Potential therapeutic targets of triple-negative breast cancer based on its intrinsic subtype. Oncotarget 2017, 8, 73329-73344. [CrossRef]

7. Dardare, J.; Witz, A.; Merlin, J.L.; Gilson, P.; Harlé, A. SMAD4 and the TGF $\beta$ Pathway in Patients with Pancreatic Ductal Adenocarcinoma. Int. J. Mol. Sci. 2020, 21, 3534. [CrossRef]

8. Derynck, R.; Turley, S.J.; Akhurst, R.J. TGF $\beta$ biology in cancer progression and immunotherapy. Nat. Rev. Clin. Oncol. 2021, 18, 9-34. [CrossRef]

9. Xu, X.; Zhang, L.; He, X.; Zhang, P.; Sun, C.; Xu, X.; Lu, Y.; Li, F. TGF- $\beta$ plays a vital role in triple-negative breast cancer (TNBC) drug-resistance through regulating stemness, EMT and apoptosis. Biochem. Biophys. Res. Commun. 2018, 502, 160-165. [CrossRef]

10. Neuzillet, C.; Hammel, P.; Tijeras-Raballand, A.; Couvelard, A.; Raymond, E. Targeting the Ras-ERK pathway in pancreatic adenocarcinoma. Cancer Metastasis Rev. 2013, 32, 147-162. [CrossRef]

11. Gupta, G.K.; Collier, A.L.; Lee, D.; Hoefer, R.A.; Zheleva, V.; Siewertsz van Reesema, L.L.; Tang-Tan, A.M.; Guye, M.L.; Chang, D.Z.; Winston, J.S.; et al. Perspectives on Triple-Negative Breast Cancer: Current Treatment Strategies, Unmet Needs, and Potential Targets for Future Therapies. Cancers 2020, 12, 2392. [CrossRef] [PubMed]

12. Lehmann, K.; Janda, E.; Pierreux, C.E.; Rytömaa, M.; Schulze, A.; McMahon, M.; Hill, C.S.; Beug, H.; Downward, J. Raf induces TGFbeta production while blocking its apoptotic but not invasive responses: A mechanism leading to increased malignancy in epithelial cells. Genes Dev. 2000, 14, 2610-2622. [CrossRef] [PubMed]

13. Pardoux, C.; Derynck, R. JNK regulates expression and autocrine signaling of TGF-beta1. Mol. Cell 2004, 15, 170-171. [CrossRef] 
14. Van Obberghen-Schilling, E.; Roche, N.S.; Flanders, K.C.; Sporn, M.B.; Roberts, A.B. Transforming growth factor beta 1 positively regulates its own expression in normal and transformed cells. J. Biol. Chem. 1988, 263, 7741-7746. [CrossRef]

15. Zhang, M.; Fraser, D.; Phillips, A. ERK, p38, and Smad signaling pathways differentially regulate transforming growth factor-beta1 autoinduction in proximal tubular epithelial cells. Am. J. Pathol. 2006, 169, 1282-1293. [CrossRef]

16. Ungefroren, H.; Otterbein, H.; Wellner, U.F.; Keck, T.; Lehnert, H.; Marquardt, J.U. RAC1B Regulation of TGFB1 Reveals an Unexpected Role of Autocrine TGF $\beta 1$ in the Suppression of Cell Motility. Cancers 2020, 12, 3570. [CrossRef] [PubMed]

17. Witte, D.; Otterbein, H.; Forster, M.; Giehl, K.; Zeiser, R.; Lehnert, H.; Ungefroren, H. Negative regulation of TGF-beta1-induced MKK6-p38 and MEK-ERK signalling and epithelial-mesenchymal transition by Rac1b. Sci. Rep. 2017, 7, 17313. [CrossRef] [PubMed]

18. Wang, J.; Sergina, N.; Ko, T.C.; Gong, J.; Brattain, M.G. Autocrine and exogenous transforming growth factor beta control cell cycle inhibition through pathways with different sensitivity. J. Biol. Chem. 2004, 279, 40237-40244. [CrossRef] [PubMed]

19. Wu, S.P.; Sun, L.-Z.; Willson, J.K.V.; Fields, K.; Humphrey, L.E.; Brattain, M.G. Repression of autocrine TGF- $\beta 1$ and $\beta 2$ in quiescent CBS colon carcinoma cells leads to progression of tumorigenic properties. Cell Growth Diff. 1993, 4, 115-123. [PubMed]

20. Lei, X.; Yang, J.; Nichols, R.W.; Sun, L.Z. Abrogation of TGFbeta signaling induces apoptosis through the modulation of MAP kinase pathways in breast cancer cells. Exp. Cell Res. 2007, 313, 1687-1695. [CrossRef]

21. Safina, A.; Vandette, E.; Bakin, A.V. ALK5 promotes tumor angiogenesis by upregulating matrix metalloproteinase-9 in tumor cells. Oncogene 2007, 26, 2407-2422. [CrossRef]

22. Yu, N.; Kozlowski, J.M.; Park, I.I.; Chen, L.; Zhang, Q.; Xu, D.; Doll, J.A.; Crawford, S.E.; Brendler, C.B.; Lee, C. Overexpression of transforming growth factor $\beta 1$ in malignant prostate cells is partly caused by a runaway of TGF- $\beta 1$ auto-induction mediated through a defective recruitment of protein phosphatase 2A by TGF- $\beta$ type I receptor. Urology 2010, 76, e8-e13. [CrossRef]

23. Liu, Z.; Bandyopadhyay, A.; Nichols, R.W.; Wang, L.; Hinck, A.P.; Wang, S.; Sun, L.Z. Blockade of Autocrine TGF-beta Signaling Inhibits Stem Cell Phenotype, Survival, and Metastasis of Murine Breast Cancer Cells. J. Stem Cell Res. Ther. 2012, 2, 1-8. [CrossRef]

24. Yang, H.; Kyo, S.; Takatura, M.; Sun, L. Autocrine transforming growth factor beta suppresses telomerase activity and transcription of human telomerase reverse transcriptase in human cancer cells. Cell Growth Diff. 2001, 12, 119-127. [PubMed]

25. Baker, K.; Raut, P.; Jass, J.R. Microsatellite unstable colorectal cancer cell lines with truncating TGFbetaRII mutations remain sensitive to endogenous TGFbeta. J. Pathol. 2007, 213, 257-265. [CrossRef]

26. Daroqui, M.C.; Vazquez, P.; Bal de Kier Joffé, E.; Bakin, A.V.; Puricelli, L.I. TGF- $\beta$ autocrine pathway and MAPK signaling promote cell invasiveness and in vivo mammary adenocarcinoma tumor progression. Oncol. Rep. 2012, 28, 567-575. [CrossRef] [PubMed]

27. Handler, J.; Cullis, J.; Avanzi, A.; Vucic, E.A.; Bar-Sagi, D. Pre-neoplastic pancreas cells enter a partially mesenchymal state following transient TGF-beta exposure. Oncogene 2018, 37, 4334-4342. [CrossRef]

28. Ungefroren, H. Autocrine TGF- $\beta$ in Cancer: Review of the Literature and Caveats in Experimental Analysis. Int. J. Mol. Sci. 2021, 22, 977. [CrossRef]

29. Voss, M.; Wolff, B.; Savitskaia, N.; Ungefroren, H.; Deppert, W.; Schmiegel, W.; Kalthoff, H.; Naumann, M. TGFbeta-induced growth inhibition involves cell cycle inhibitor p21 and pRb independent from p15 expression. Int. J. Oncol. 1999, 14, 93-101. [CrossRef] [PubMed]

30. Koo, B.H.; Kim, Y.; Je Cho, Y.; Kim, D.S. Distinct roles of transforming growth factor-beta signaling and transforming growth factor-beta receptor inhibitor SB431542 in the regulation of p21 expression. Eur. J. Pharmacol. 2015, 764, 413-423. [CrossRef] [PubMed]

31. Hobbs, F.; Copeland, R.A.; Magolda, R.L.; Scherle, P.A.; Trzaskos, J.M. Identification of a novel inhibitor of mitogen-activated protein kinase kinase. J. Biol. Chem. 1998, 273, 18623-18632.

32. Horiguchi, K.; Shirakihara, T.; Nakano, A.; Imamura, T.; Miyazono, K.; Saitoh, M. Role of Ras signaling in the induction of snail by transforming growth factor-beta. J. Biol. Chem. 2009, 284, 245-253. [CrossRef]

33. Giehl, K.; Seidel, B.; Gierschik, P.; Adler, G.; Menke, A. TGFbeta1 represses proliferation of pancreatic carcinoma cells which correlates with Smad4-independent inhibition of ERK activation. Oncogene 2000, 19, 4531-4541. [CrossRef]

34. Riesco-Eizaguirre, G.; Rodríguez, I.; De la Vieja, A.; Costamagna, E.; Carrasco, N.; Nistal, M.; Santisteban, P. The BRAFV600E oncogene induces transforming growth factor beta secretion leading to sodium iodide symporter repression and increased malignancy in thyroid cancer. Cancer Res. 2009, 69, 8317-8325. [CrossRef] [PubMed]

35. Park, B.J.; Park, J.I.; Byun, D.S.; Park, J.H.; Chi, S.G. Mitogenic conversion of transforming growth factor-beta1 effect by oncogenic Ha-Ras-induced activation of the mitogen-activated protein kinase signaling pathway in human prostate cancer. Cancer Res. 2000, 60, 3031-3038. [PubMed]

36. Ungefroren, H.; Witte, D.; Fiedler, C.; Gädeken, T.; Kaufmann, R.; Lehnert, H.; Gieseler, F.; Rauch, B.H. The Role of PAR2 in TGF- $\beta 1$-Induced ERK Activation and Cell Motility. Int. J. Mol. Sci. 2017, 18, 2776. [CrossRef]

37. Lee, M.K.; Pardoux, C.; Hall, M.C.; Lee, P.S.; Warburton, D.; Qing, J.; Smith, S.M.; Derynck, R. TGF-beta activates Erk MAP kinase signalling through direct phosphorylation of ShcA. EMBO J. 2007, 26, 3957-3967. [CrossRef] [PubMed]

38. Muthusamy, B.P.; Budi, E.H.; Katsuno, Y.; Lee, M.K.; Smith, S.M.; Mirza, A.M.; Akhurst, R.J.; Derynck, R. ShcA Protects against Epithelial-Mesenchymal Transition through Compartmentalized Inhibition of TGF-beta-Induced Smad Activation. PLoS Biol. 2015, 13, e1002325. [CrossRef] 
39. Inman, G.J.; Nicolás, F.J.; Callahan, J.F.; Harling, J.D.; Gaster, L.M.; Reith, A.D.; Laping, N.J.; Hill, C.S. SB-431542 is a potent and specific inhibitor of transforming growth factor-beta superfamily type I activin receptor-like kinase (ALK) receptors ALK4, ALK5, and ALK7. Mol. Pharmacol. 2002, 62, 65-74. [CrossRef]

40. Principe, D.R.; Diaz, A.M.; Torres, C.; Mangan, R.J.; DeCant, B.; McKinney, R.; Tsao, M.S.; Lowy, A.; Munshi, H.G.; Jung, B.; et al. TGF $\beta$ engages MEK/ERK to differentially regulate benign and malignant pancreas cell function. Oncogene 2017, 36, 4336-4348. [CrossRef]

41. Ungefroren, H.; Sebens, S.; Growth, S.; Gieseler, F.; Fändrich, F. The Src family kinase inhibitors PP2 and PP1 block TGF-beta1mediated cellular responses by direct and differential inhibition of type I and type II TGF-beta receptors. Curr. Cancer Drug Targets 2011, 11, 524-535. [CrossRef] [PubMed]

42. Cuenda, A.; Rouse, J.; Doza, Y.N.; Meier, R.; Cohen, P.; Gallagher, T.F.; Young, P.R.; Lee, J.C. SB 203580 is a specific inhibitor of a MAP kinase homologue which is stimulated by cellular stresses and interleukin-1. FEBS Lett. 1995, 364, $229-233$.

43. Ungefroren, H.; Otterbein, H.; Fiedler, C.; Mihara, K.; Hollenberg, M.D.; Gieseler, F.; Lehnert, H.; Witte, D. RAC1B Suppresses TGF- $\beta 1$-Dependent Cell Migration in Pancreatic Carcinoma Cells through Inhibition of the TGF- $\beta$ Type I Receptor ALK5. Cancers 2019, 11, 691. [CrossRef]

44. Kretschmer, A.; Moepert, K.; Dames, S.; Sternberger, M.; Kaufmann, J.; Klippel, A. Differential regulation of TGF-beta signaling through Smad2, Smad3 and Smad4. Oncogene 2003, 22, 6748-6763. [CrossRef] [PubMed]

45. Wang, L.; Ko, C.Y.; Meyers, E.E.; Pedroja, B.S.; Pelaez, N.; Bernstein, A.M. Concentration-dependent effects of transforming growth factor $\beta 1$ on corneal wound healing. Mol. Vis. 2011, 17, 2835-2846.

46. de Ceuninck van Capelle, C.; Spit, M.; Ten Dijke, P. Current perspectives on inhibitory SMAD7 in health and disease. Crit. Rev. Biochem. Mol. Biol. 2020, 55, 691-715. [CrossRef]

47. Lei, X.; Bandyopadhyay, A.; Le, T.; Sun, L. Autocrine TGFbeta supports growth and survival of human breast cancer MDA-MB-231 cells. Oncogene 2002, 21, 7514-7523. [CrossRef]

48. Dunfield, L.D.; Nachtigal, M.W. Inhibition of the antiproliferative effect of TGFbeta by EGF in primary human ovarian cancer cells. Oncogene 2003, 22, 4745-4751. [CrossRef]

49. Wang, S.E.; Yu, Y.; Criswell, T.L.; Debusk, L.M.; Lin, P.C.; Zent, R.; Johnson, D.H.; Ren, X.; Arteaga, C.L. Oncogenic mutations regulate tumor microenvironment through induction of growth factors and angiogenic mediators. Oncogene 2010, 29, 3335-3348. [CrossRef]

50. Geiser, A.G.; Busam, K.J.; Kim, S.J.; Lafyatis, R.; O’Reilly, M.A.; Webbink, R.; Roberts, A.B.; Sporn, M.B. Regulation of the transforming growth factor-beta 1 and -beta 3 promoters by transcription factor Sp1. Gene 1993, 129, 223-228. [CrossRef]

51. Tiwari, A.; Iida, M.; Kosnopfel, C.; Abbariki, M.; Menegakis, A.; Fehrenbacher, B.; Maier, J.; Schaller, M.; Brucker, S.Y.; Wheeler, D.L.; et al. Blocking Y-Box Binding Protein-1 through Simultaneous Targeting of PI3K and MAPK in Triple Negative Breast Cancers. Cancers 2020, 12, 2795. [CrossRef] [PubMed]

52. Miyazono, K. Transforming growth factor-beta signaling in epithelial-mesenchymal transition and progression of cancer. Proc. Jpn. Acad. Ser. B Phys. Biol. Sci. 2009, 85, 314-323. [CrossRef] [PubMed]

53. Zinn, R.; Otterbein, H.; Lehnert, H.; Ungefroren, H. RAC1B: A guardian of the epithelial phenotype and protector against epithelial-mesenchymal transition. Cells 2019, 8, 1569. [CrossRef] [PubMed]

54. Lowenfels, A.B.; Maisonneuve, P.; Cavallini, G.; Ammann, R.W.; Lankisch, P.G.; Andersen, J.R.; Dimagno, E.P.; Andrén-Sandberg, A.; Domellöf, L. Pancreatitis and the risk of pancreatic cancer. International Pancreatitis Study Group. N. Engl. J. Med. 1993, 328, 1433-1437. [CrossRef]

55. Hass, R.; von der Ohe, J.; Ungefroren, H. The Intimate Relationship Among EMT, MET and TME: A T(ransdifferentiation) E(nhancing) M(ix) to Be Exploited for Therapeutic Purposes. Cancers 2020, 12, 3674. [CrossRef]

56. Aiello, N.M.; Kang, Y. Context-dependent EMT programs in cancer metastasis. J. Exp. Med. 2019, 216, 1016-1026. [CrossRef]

57. Gao, Y.; Dickerson, J.B.; Guo, F.; Zheng, J.; Zheng, Y. Rational design and characterization of a Rac GTPase-specific small molecule inhibitor. Proc. Natl. Acad. Sci. USA 2004, 101, 7618-7623. [CrossRef] [PubMed]

58. Regala, R.P.; Weems, C.; Jamieson, L.; Copland, J.A.; Thompson, E.A.; Fields, A.P. Atypical protein kinase Ciota plays a critical role in human lung cancer cell growth and tumorigenicity. J. Biol. Chem. 2005, 280, 31109-31115. [CrossRef] 